\title{
A Case of Xanthogranulomatous Sialadenitis with Facial Palsy Mimicking Malignancy
}

\author{
Sang Hyun Kim ${ }^{\mathbb{D}}$, Sun Woo Kim, and Sang Hyuk Lee \\ Department of Otorhinolaryngology-Head and Neck Surgery, Kangbuk Samsung Hospital, Sungkyunkwan University \\ School of Medicine, Seoul, Korea
}

\section{악성 병변으로 오인된 안면마비를 동반한 황색육아종성 침샘염 1예}

김상현 · 김선우 · 이상혁

성균관대학교 의과대학 강북삼성병원 이비인후과학교실

\author{
Received May 8, 2020 \\ Revised June 19,2020 \\ Accepted June 22, 2020 \\ Address for correspondence \\ Sang Hyuk Lee, MD \\ Department of Otorhinolaryngology- \\ Head and Neck Surgery, \\ Kangbuk Samsung Hospital, \\ Sungkyunkwan University \\ School of Medicine, \\ 29 Saemunan-ro, Jongno-gu, \\ Seoul 03181, Korea \\ Tel $+82-2-2001-2269$ \\ Fax $+82-2-2001-2273$
}

E-mail entlsh@hanmail.net
Parotid mass with facial palsy is often suggestive of malignancy. Facial palsy is present in $12 \%$ to $19 \%$ of patients with a malignant parotid mass regardless of tumor size. Xanthogranulomatous sialadenitis is a rare chronic inflammatory disorder. This is characterized by suppurative granulomatous inflammation and progressive destruction of the normal parenchyma. Since its first report in 1993, xanthogranulomatous sialadenitis has been reported in no more than 10 reports abroad, and to our knowledge, it has never been reported in Korea. It is hard to distinguish clinically xanthogranulomatous sialadenitis from malignancy because they have similar clinical symptoms and radiologic findings, so they should be diagnosed with pathologic methods. With a review of literature, the authors report a case of a parotid mass considered malignant in a 62-year-old, who has complained of a painful right parotid mass and ipsilateral facial palsy. The patient was managed by superficial parotidectomy and conservative antibitoic therapy. Korean J Otorhinolaryngol-Head Neck Surg 2021;64(6):422-8

Key Words Facial paralysis · Parotid gland abscess · Parotid gland · Parotid neoplasm · Xanthogranulomatous sialadenitis.

\section{서 론}

이하선 종양은 흔히 귀 밑의 무통성 종물로 만져지며, 대 부분 오랜 기간에 걸쳐 천천히 크기가 증가한다. 종양의 갑작 스런 크기 증가는 양성 종괴의 악성 변화를 의심해야 하며, 종양의 크기 증가에 따른 혈류의 장애로 종양의 괴사 및 염 증 반응이 나타나고 이로 인해 갑작스러운 통증이 동반될 수 있다. 그 외 안면마비, 종괴의 고정성, 경부 림프절 비대가 동 반되는 이하선 종양은 악성 종양의 가능성을 고려해야 한 다.) 이하선 종괴를 동반한 안면마비는 흔히 악성 종양과 관

This is an Open Access article distributed under the terms of the Creative Commons Attribution Non-Commercial License (https://creativecommons.org/licenses/by-nc/4.0) which permits unrestricted non-commercial use, distribution, and reproduction in any medium, provided the original work is properly cited.
련있으며 양성 종양이 안면마비를 유발하는 것은 드문 것으 로 보고되어 있다. ${ }^{2,3}$

황색육아종성 염증반응(xanthogranulomatous reaction) 은 화농성 육아종성 염증조직을 특징으로 하는 만성 염증 반응 중 한 형태이다. 이 병변은 흔히 신장에서 발견되는 화 농성 신장 감염의 합병증 중 하나로 알려져 있다. 이외 담낭, 골반 내 등에서 발견되나 이하선에서 발견된 경우는 거의 없 다. 특히 황색육아종성 침샘염은 이하선에서 현재 9예, 악하 선에서 1 예의 보고밖에 없을 정도로 굉장히 드문 질환이 다.,4-11) 이하선에서 발생하는 경우에서 주 증상은 이하선의 종괴성 병변 및 통증으로 보고되어 있으며 항생제 치료에도 크게 호전이 없다. 영상학적 소견은 비특이적이고 악성 종양 과 유사하게 보인다. 수술 전 세포조직학적 검사 또한 황색육 
아종성 침샘염을 의심하기 어려운, 단순 염증 소견으로 나타 난다. 이는 악성 종양과 감별이 어려운 소견으로 대부분 수술 후 절제조직에서 확진된다. 현재까지 명확히 제시된 진단방법 및 치료방법 역시 알려진 것이 없다.

저자들은 천천히 커지는 우측 이하선의 종괴가 통증 및 동 측 안면마비를 동반하여, 악성 종양으로 강력히 의심되었던 62세 남환에서 황색육아종성 침샘염(xanthogranulomatous sialadenitis)으로 진단된 증례를 치험하였기에 문헌 고찰과 함께 보고하는 바이다.

\section{증 례}

특이 기왕력이 없는 62세 남자 환자가 내원 3년 전부터 서 서히 자라온 우측 귀 밑의 종괴를 주소로 본원 이비인후과로 내원하였다. 우측 이하선 종괴는 1달 전부터 통증 및 안면마 비, 개구 장애를 동반하였다. 이학적 검사상 우측 이하선의 $6 \mathrm{~cm}$ 크기의 압통을 동반한 단발성 종괴가 만져졌으며 촉진
시에 압통을 동반했으나 저명한 열감은 없었다. 이하선 주변 부 및 경부 림프절의 비대는 촉지되지 않았으며, House Brackmann grade $\mathrm{V}$ 수준의 안면마비가 관찰되었다. 신경전 도검사상에서 환측 눈 둘레근(orbicularis oculi muscle)은 건측과 비교하여 $16 \%$, 입꼬리당김근(risorius muscle)은 $23 \%$ 수준의 진폭을 보였다.

시행한 경부 컴퓨터단층촬영 $(\mathrm{CT})$ 검사에서 약 $3.8 \times 4.6 \times$ $5.4 \mathrm{~cm}$ 크기의 저음영으로 불규칙하게 조영되는 경계부가 보 이고 일부 중격 형성이 관찰되는 타원형 종괴가 우측 이하선 에서 관찰되었고, 이 외 관찰되는 경부 림프절의 비대는 보이 지 않았다. 경부 자기공명영상(MRI)에서는 $3.8 \times 5.2 \times 5.8 \mathrm{~cm}$ 크기 우측 이하선 내부의 $\mathrm{T} 2$ 강조영상에서는 고신호 강도 및 일부 저신호 강도의 병소들이 보였으며 T1강조영상에서는 불 균질한 고신호 강도 및 저신호 강도가 섞여있는 양상의 종괴 가 우측 이하선에서 관찰되었다. 조영된 $\mathrm{T} 1$ 강조영상에서는 내부 중격이 형성되어있는 낭성 종괴가 우측 이하선에서 관 찰되었다(Fig. 1). 이는 우측 이하선의 점액표피양암종 혹은
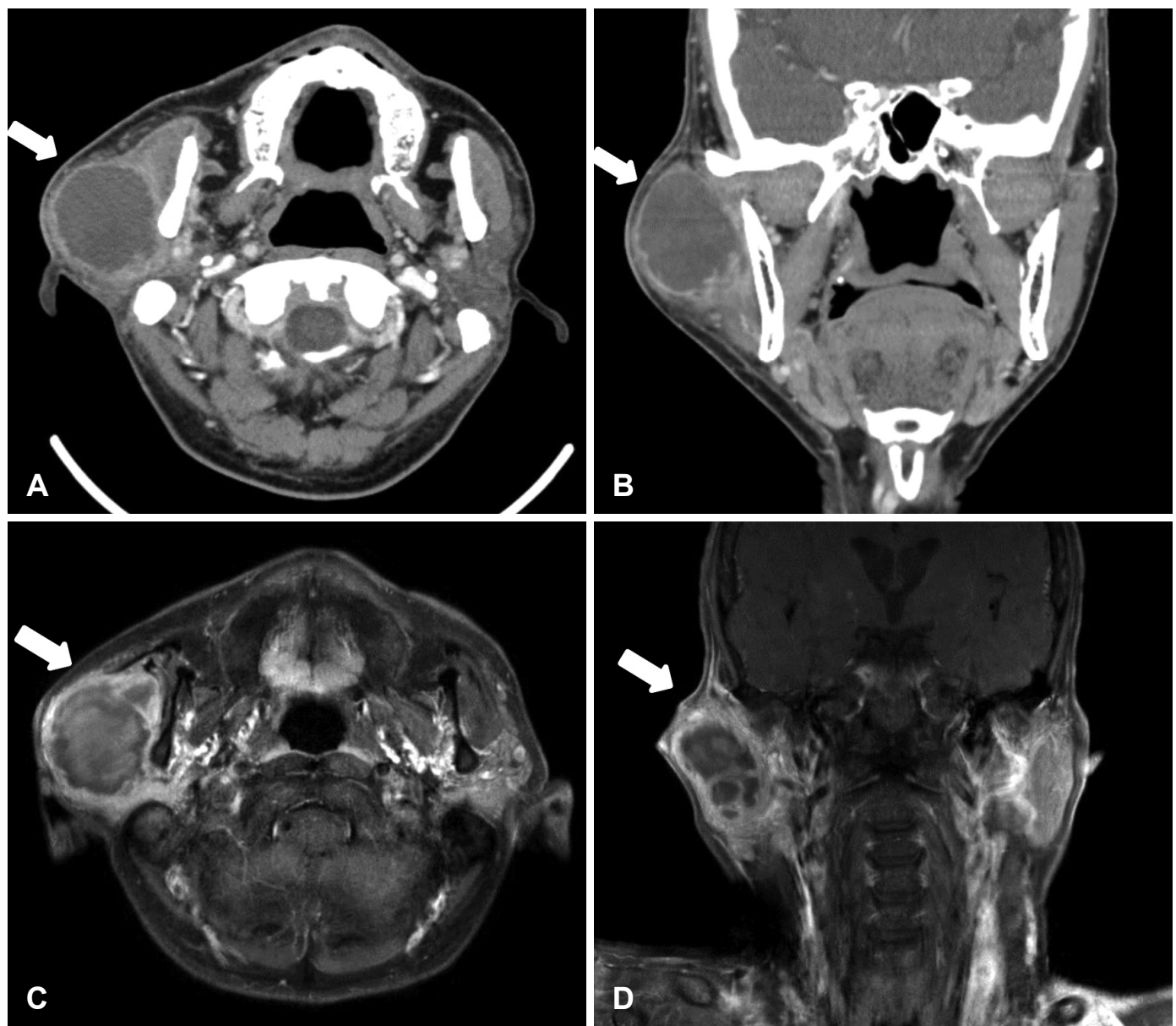

Fig. 1. Neck CT \& MRI. Preoperative axial (A) and coronal (B) CT image. Enhanced neck CT scan revealed a $3.8 \times 4.6 \times 5.4 \mathrm{~cm}$ large well-defined, irregular wall enhancement and internal septation cystic mass (arrow) at the right parotid gland. Preoperative axial (C) and coronal (D) T1 weighted enhanced MRI image. A $5.3 \times 3.8 \times 5.2 \mathrm{~cm}$ cystic mass (arrow) was revealed with internal septation and irregular wall thickening. Heterogeneous low and high signal intensity lesion is mixed in the cyst. 
이하선 농양을 의심할 수 있는 소견이었으나 명확한 진단 방 향을 잡기 어려운 소견이었다.

악성 종양을 감별하기 위하여 중심바늘생검을 통해 2군데 에서 조직병리검사를 시행하였다. 현미경 검사상 섬유성 간질 (fibrotic stroma)과 함께 중성구(neutrophils), 조직구(histiocytes), 림프구(lymphocytes)가 보이는 혼재된 염증세포의 소견이 관찰되었다. 뚜렷한 악성 종양의 소견은 관찰되지 않 았다. 그러나 3 년간 서서히 커져온 우측 이하선의 종괴 및 1달 전 시작된 통증, 안면마비의 임상양상과 영상 소견을 고려했 을 때 이하선의 종물은 단순한 농양보다는 종양성 병변에 동 반된 염증성 반응으로 생각되었다.

시행한 혈액검사상 C-reactive protein 수치 $12 \mathrm{mg} / \mathrm{dL}$ 을 보여 염증성 병변이 의심되었으나 white blood cell 7570× $1000 / \mathrm{mm}^{3}$ 소견을 보였고 흥부 방사선검사 및 심전도 검사상 특이소견 보이지 않았다. 저자들은 이상의 결과로 우측 침샘 농양, 점액표피모양암종, 선낭암종(adenocystic carcinoma) 등을 의심하였다.

우측 이하선의 염증성 병변 및 농양으로 의심되는 병변에 대하여 입원 직후 amoxicillin-clavulanate $1.2 \mathrm{~g} 1$ 일 3회 및 metronidazole $500 \mathrm{mg}$ 1일 3회 정맥내로 11 일간 투여, 5일 간의 isepamicin $100 \mathrm{mg}$ 1일 2회 근주의 항생제 투여로 보 존적 치료를 하였고, 11일 후 C-reactive protein $0.77 \mathrm{mg} / \mathrm{dL}$ 수준으로 감소했으나 종괴 크기의 감소 및 안면마비 정도의 호전은 없었고 우측 이하선의 통증은 지속되었다. 이에 이하 선 악성 종양의 감별과 진단 및 치료의 목적으로 수술적 제 거를 계획하였다.

전신마취 및 신경 감시 장치하 수술을 진행하였다. Modified blair incision으로 피부절개하였으며 우측 이하선의 $5 \times$
$5 \mathrm{~cm}$ 크기의 낭성 종괴가 보였고 주변부와 심한 유착이 관 찰되었으나 조심스럽게 박리하였다. 절제된 자리에서는 유착 과 섬유화가 진행된 소견이 보였으나 안면신경의 침범 소견은 관찰되지 않았다. 절제된 낭성 종괴에선 갈색의 점액성 및 장 액성 분비물이 다량 나왔으며 세균검사를 시행하였다. 당시 시행한 동결절편 검사에서는 염증조직 소견 외 특이사항은 없었다. 수술은 이하선 천엽 절제술로 마무리되었고 관자엽, 광대부, 협부, 하악연 줄기의 안면신경은 보존되었다(Fig. 2).

절제된 검체의 조직검사 소견에서 우측 이하선의 정상 실 질을 침범하는 거품양 조직구(foamy hystiocyte) 및 림프구, 중성구 등이 관찰되었다. 또한 농양 및 낭성 변화, 위축성 이 하선과 그 내부에 지방 침착 및 cholesterol cleft를 동반한 황색육아종성 침샘염 소견을 보였다(Fig. 3). 와르틴 종양을 의심할 수 있는 호산과립세포(oncocyte) 등의 소견은 관찰되 지 않았고 악성 종양을 의심할 만한 소견도 없었다. 면역조직 화학 검사상에서는 S-100, CD1a 음성이었으며 CD68 양성 으로 나타났다. 당시 절제된 검체 내 분비물에서 시행된 균검 사상에서 Klebsiella pneumonia 배양되었다. 수술 이후 현 재까지 6개월동안 경과 관찰했으며 안면마비의 호전은 없었 으나 종괴의 재발, 통증 등의 소견은 관찰되지 않았다.

\section{고 찰}

이하선 종괴의 통증 및 크기 변화는 대부분 염증 반응이나 낭종성 변성, 종양 내 출혈 등이 원인이며 악성 종양에서도 종괴 크기 증가에 따른 혈류 장애로 괴사 및 염증반응이 유 발될 수 있다. ${ }^{12)}$ 갑작스런 통증 및 부종 외에도 안면마비, 고 정된 종괴, 경부 림프절 비대를 동반하는 경우엔 반드시 악성
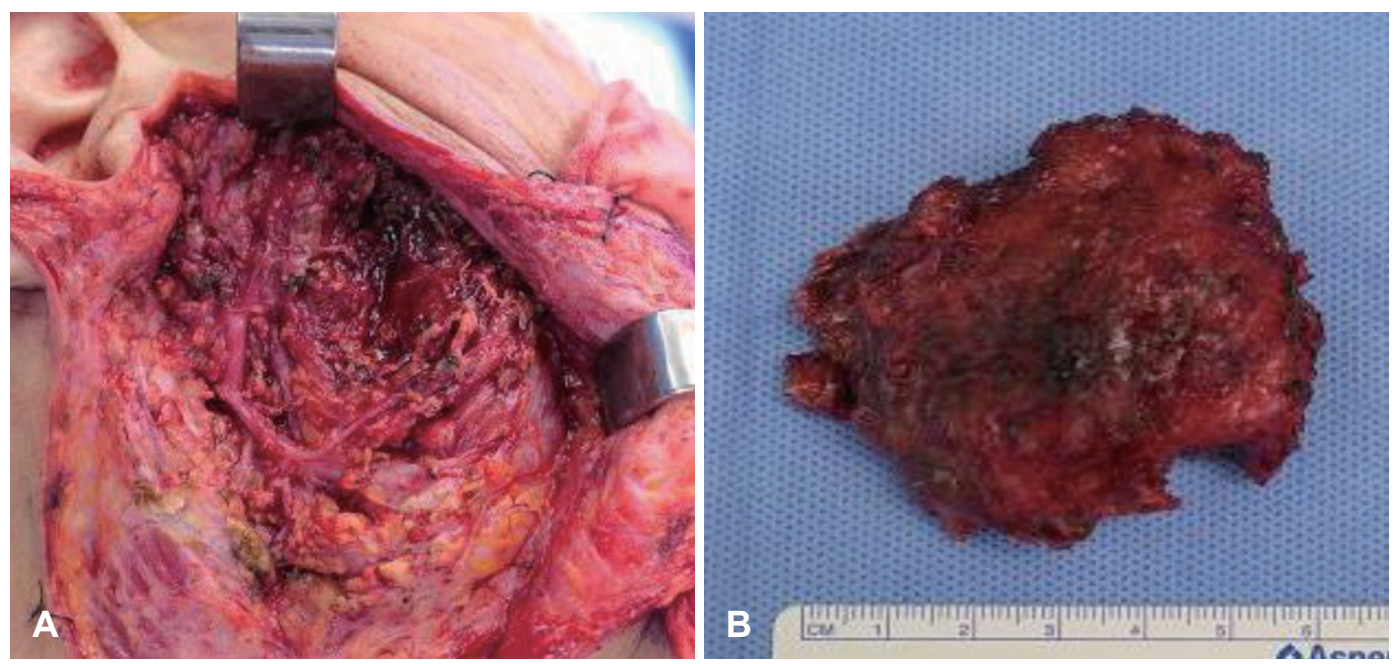

Fig. 2. Intraoperative photograph. Facial nerve main trunk and temporal, zygomatic, buccal, marginal mandibular branch were preserved (A). Intraoperartivephotograph shows about $6 \times 6 \mathrm{~cm}$ sized cystic mass. Necrotic tissue located at around mass. Brown color discharge and pus like discharge was drained from the mass $(\mathrm{B})$. 

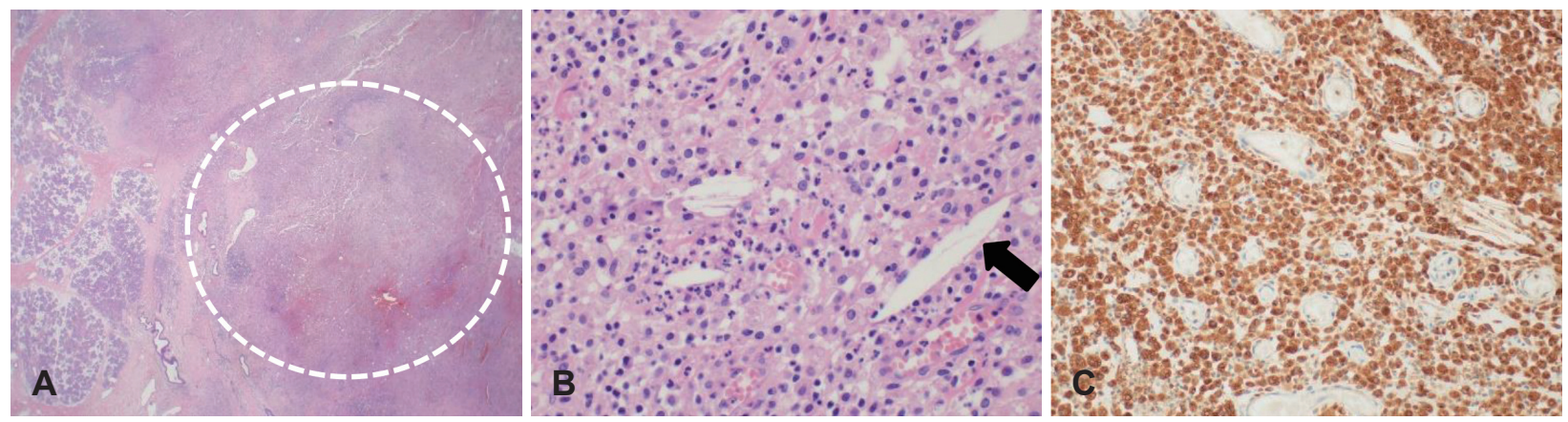

Fig. 3. Pathologic finding. Sections reveal extensive collection of foamy histiocytes and some admixed inflammatory cells (circle) (H\&E, $\times 12.5)(A)$. There are foamy histiocytic collections with cholesterol clefts (arrow) and some neutrophils (H\&E, $\times 400)(B)$. Immunohistochemical staining: CD68 stains reveal diffusely positive reaction. CD68 is a protein highly expressed by cells in the monocyte lineage by circulating macrophages, and by tissue macrophages (CD68 stain, $\times 200)(C)$. H\&E: hematoxylin and eosin, CD68: cluster of differentiation 68.

종양을 감별해야 한다. 이하선 악성 종양의 $10 \%$ 정도는 진단 당시 신경 침범에 의한 안면마비를 보인다. 양성 종양과 농양 으로도 독성을 가진 세균, 신경주위염, 신경압박에 의해서 안 면마비가 발생할 수 있으나 극히 드문 것으로 알려져있다. 2,13) 이하선 종양은 영상 검사를 통해 주변 조직의 침범 정도 및 심부 종양의 위치를 파악할 수 있으며, 악성에서는 불규칙한 경계 및 뇌기저부의 파괴, 림프절 비대, 외부 조직 침범 소견 등을 관찰할 수 있다. 악성 종양의 진단에 있어서는 조직학적 검사가 필수적이나, 조직검사상 양성 소견일지라도 안면마비 혹은 림프절 비대를 동반하였거나 영상 검사에서 악성 소견이 의심되는 경우 이에 대한 수술적 치료를 망설여서는 안된다.

본 증례에서는 영상검사상 명확한 주변 조직의 침범 소견 은 없었으나 염증과 악성 종양을 구분하기 어려운 소견이 보 였다. 시행한 침생검 조직병리검사에서도 섬유화된 간질 및 염증 조직의 소견 외에 종양 세포 및 악성 병변을 의심할 수 있는 소견은 관찰되지 않았다. 그러나 이전 알려진 문헌에 따 르면 임상양상과 영상학적 검사를 고려했을 때 악성 종양을 충분히 의심할 수 있는 상황에서는 악성에 준한 적극적인 수 술적 치료를 권하였다. ${ }^{12}$ 3년동안 커진 우측 이하선 종괴가 1 달 전부터 갑작스런 통증과 열감, 안면마비를 동반한 점으 로 악성 종양의 가능성을 염두하여 수술을 진행하였고 당시 시행한 동결절편 조직검사 결과에서 염증 소견 이외의 특정 한 양성 및 악성 종양은 관찰되지 않아서 이하선 천엽 절제 술로 수술은 마무리 되었다. 수술 후의 조직검사 결과는 황 색육아종성 침샘염이었다.

황색육아종성 조직반응은 화농성 육아종을 동반한 정상 실질의 점진적인 파괴를 특징으로 하는 만성 염증반응의 일 종이다. 중년의 여성에서 흔하고 주로 신장 및 담낭에서 주로 발생하며 이 외 피부, 임파선, 전립선, 자궁 내막 등 다양한 장기에서 발생할 수 있는 것으로 알려져 있다. 신장 및 담낭 에서 발생하는 황색육아종성 조직반응은 주로 배액 장애와
연관이 있을 것으로 생각되나 황색육아종성 침샘염의 원인 은 명확히 알려져 있지 않다. Stephen 등은 황색육아종성 침샘염이 미세침흡인생검에 의해 유발된 합병증일 수 있음을 언급했다. 혹자는 와르틴 종양이 미세침흡인생검에 의해 괴 사되거나 혹은 그 외의 원인으로 자연 괴사되며 발생한 염증 반응으로 황색육아종성 침샘염이 발생했을 것으로 주장하였 다. ${ }^{1)}$ 이들이 보고한 증례에서는 일반적인 와르틴 종양이 통 증이 없고 완만한 증식 속도를 보이는 것과 달리 통증과 부 종을 동반했다. 저자는 이런 현상이 와르틴 종양에서 미세침 흡인생검으로 인해 종괴의 괴사 및 염증 반응이 발생한 것이 라 설명했다. 이처럼 와르틴 종양이 쉽게 괴사하는 이유는 와 르틴 종양이 낭성 공간을 만들며 생긴 혈류 공급의 장애가 결국 종괴의 염증과 괴사를 유발했을 것이라 덧붙였다. 또한 와르틴 종양이 최종 조직에서 관찰되지 않은 환자도 있었는 데, 이는 종양의 괴사 이후 와르틴 종양의 소실로 관찰되지 않았을 것이라 설명하였다. 그러나 또 다른 문헌은 수술 이전 미세침흡인생검 당시에 이미 일련의 염증 소견이 관찰된 점 등으로 황색육아종성 침샘염은 미세침흡인생검의 합병증일 가능성은 떨어진다 언급했다. 또한 미세침흡인생검에서 와르 틴 종양으로 진단되었으나 최종 절제 조직생검에서 와르틴 종양의 소견은 관찰되지 않은 예를 통해서 와르틴 종양과도 크게 관계가 없을 것이라 언급했다.7) 본 증례에서도 와르틴 종양의 소견은 관찰되지 않았었다.

황색육아종성 침샘염의 임상양상은 농양을 동반한 종양 성 병변과 유사하며 영상학적 검사상 낭성 종괴의 형태로 보 이기 때문에 악성 병변과의 감별이 어렵다. 특히 신장 및 담 낭부 등 다른 장기에서도 암종과 유사한 영상학적 소견으로 수술 전 진단이 어려운 것으로 보고되어 있다.5,14) 이뿐 아니 라 황색육아종성 침샘염의 적은 증례도 진단을 더욱 어렵게 만든다. 침샘에서 발생한 황색육아종성 염증반응은 거의 보 고된 바 없으며 현재까지 이하선의 9예, 악하선에서 1예가 보 
고되어 있다. 보고된 황색육아종성 침샘염 환자들은 경계가 뚜렷하지 않은 귀 밑의 종괴와 통증, 점진적인 크기의 증가 및 압통을 주로 호소하였다. 대부분의 환자에서 항생제 사용 에도 크게 통증의 호전 및 크기의 감소가 보이지 않았다. ${ }^{7)}$

절제된 황색육아종성 병변의 현미경적 소견은 지방을 가 득 함유한 거품양 대식세포, cholesterol cleft가 특징적이며 다양한 숫자의 림프구, 호중구, 형질세포로 구성된 염증 양상 의 조직에 혼재되어 보인다. 병변에 따라서 간혹 중심부의 괴 사 및 미세 농양들이 거품양 조직구들에 둘러 쌓여 보이기도 한다. 급성 및 만성 염증세포 및 조직의 섬유화가 관찰되며, 표피양세포 및 다핵세포를 포함한 울타리 모양의 괴사된 육 아종 소견이 보인다. 오래된 병변에서는 혈관 형성과 함께 섬 유모세포가 관찰되기도 하였다. 면역조직화학 염색 현미경 검사상에서는 CD68 양성을 보였고 상피세포(epithelial cell) 표지자는 음성을 보인다. ${ }^{7)} \mathrm{CD} 68$ 는 단핵구 계통의 세포들인 식세포(phagocyte), 파골세포(osteoclast) 및 순환 대식세포 (circulating macrophage), 조직 대식세포(tissue macrophage) 에서 고도로 발현되는 단백질의 표지자로서 염증 반응시 주 로 발현된다. 따라서 황색육아종성 반응은 만성적인 염증에 서 볼 수 있는 절제조직의 독립적인 소견으로 수술 후 현미 경 검사상 쉽게 진단할 수 있다.

그러나 수술 전 병리 소견에서는 비특이적인 염증 소견만 을 관찰할 수 있다. 이전 보고된 황색육아종성 침샘염 증례 들에서도, 수술전 시행한 미세침흡입검사상 괴사된 조직 소 견, 중성구 등이 산재된 염증성 조직파편들 혹은 와르틴 종 양에서 발견되는 호산성 과립세포가 발견되었다. ${ }^{710)}$ 수술 전 검사는 대개 세포흡인 혹은 조직의 일부를 채취하는 방식이 기 때문에 잠재된 악성 병변의 배제가 어렵다. 따라서 이하선 에서 발생한 종괴는 병리적 소견 뿐만 아니라 임상양상과 영 상학적 검사가 감별진단을 위해서 중요한데, 황색육아종성 침샘염은 임상양상과 영상학적 검사마저 악성 종양과 구분이 어렵기 때문에 진단을 위해서는 결국 종괴의 절제된 검체가 필요하다.) 결론적으로 황색육아종성 침샘염은 원인이 분명 하지 않고 임상양상, 영상학적 검사, 세포학적 검사로 악성 종 양과의 감별이 어려우며 명확히 정해진 진단방법은 없고 수 술적 절제 후에야 진단될 수 있다.

이전 증례들에서는 초기 치료로 대부분 항생제 치료를 하 였다(Table 1). 그러나 모든 증례에서 단순한 보존적 치료로 특별한 호전은 없었다. 한 증례를 제외하고 모두 수술적 절제 가 시행되었다. 원발성 황색육아종성 침샘염 환자들에서는 대부분 재발에 대한 언급은 없었으나 한 증례에서 원발성 황 색육아종성 침샘염의 재발이 보고되었다. ${ }^{11)}$ 이 증례에서는 심한 유착으로 인해 병변 부위를 완전히 제거하지 못하고 부
분 절제술(partial resection)을 시행하였다. 15 개월 후 추적 관찰상 $4 \mathrm{~cm}$ 의 크기로 이하선의 종괴 크기가 증가하여 광범 위 절제술(wide excision) 및 경부 림프절 절제술을 시행하였 으며 12 개월간 재발 소견은 보이지 않았다. 이 외의 다른 피 부병변 등의 합병증은 동반하지 않았으며 동반된 혈액암 소 견은 없었다.

대부분의 황색육아종성 침샘염의 경우 불량한 예후는 없 었으며 생존율에 크게 영향을 미치지 않았으나 한 증례에서 는 증상 발현 22개월 이후 사망하였다. ${ }^{4)}$ 환자는 우측 이하선 의 통증 및 $4 \mathrm{~cm}$ 의 종창을 주소로 내원하여 이하선에서 시 행한 절개 조직검사상 황색육아종성 침샘염 소견 및 $\mathrm{CD} 20$ 양성의 $\mathrm{B}$ 세포 및 $\mathrm{CD} 45 \mathrm{RD}$ 양성의 $\mathrm{T}$ 세포가 관찰되었다. 이 후 흥수 및 복통 증상이 동반되었고 흥수에서 황색육아종성 소견이 보였으며 소장에서 시행한 조직검사상 황색육아종성 조직반응 및 T-세포 과다 대 B-세포림프종(high-grade, Tcell-rich B-cell lymphoma)으로 진단되었다. 이 증례는 침 샘에서만 국한된 다른 증례와는 달리 흥수 및 복통, 점진적 인 우측 팔 저린감 등을 호소하였고 결과적으로 림프종에 동반한 황색육아종성 침샘염으로 진단된 경우였다.

또한 원발성 황색육아종성 침샘염은 생괴사 황색육아종 (necrobiotic xanthogranuloma)과의 감별이 필요하다. 생괴 사 황색육아종은 조직구증 증후군(histiocytosis syndrome) 의 한 종류이며 주로 전신의 피부, 안구주변의 피하조직과 폐, 심근, 후두, 인두, 소장 같은 피외 조직을 침범하는 전신질 환의 일종이다. $\mathrm{CD} 68$ 양성 및 $\mathrm{CDla}$ 음성의 비랑게르한스 세 포(non-langerhans cell) 조직구증을 보이며 침범된 장기에 서는 거품양 대식세포, 육아종, cholesterol cleft, 생괴사 등의 소견을 보여 원발성 황색육아종성 침샘염과 유사하다. 파라 단백질혈증(paraproteinemia), 단클론항체 감마글로불린혈 증(monoclonal gammopathy) 등의 혈액종양을 동반하는 경우가 흔하다고 알려져있다. 특별히 알려진 치료는 없으나 항암치료, 방사선치료, 수술적 절제, 스테로이드 주입 등의 다 양한 방법이 시도되고 있다. 따라서 자세한 문진 및 검사를 통 해서 생괴사 황색육아종의 동반 여부를 배제할 필요가 있다.

따라서 황색육아종성 침샘염이 진단되는 경우 동반된 혈 액암 및 생괴사 황색육아종 등을 포함한 기저 전신질환에 의 해 2차적으로 발생하였을 가능성에 대한 평가가 필요하며 주기적인 경과 관찰이 중요하다.

저자들은 안면마비를 동반한 이하선의 종괴를 주소로 내 원한 환자에서 문진, 영상의학적 검사 및 조직생검, 수술적 절제를 통해서 조직병리검사상 종양의 소견없이 염증만을 동반한 황색육아종성 이하선염으로 진단하였으며, 이전 증례 에서는 볼 수 없었던 안면마비를 동반하여 악성 병변과의 감 


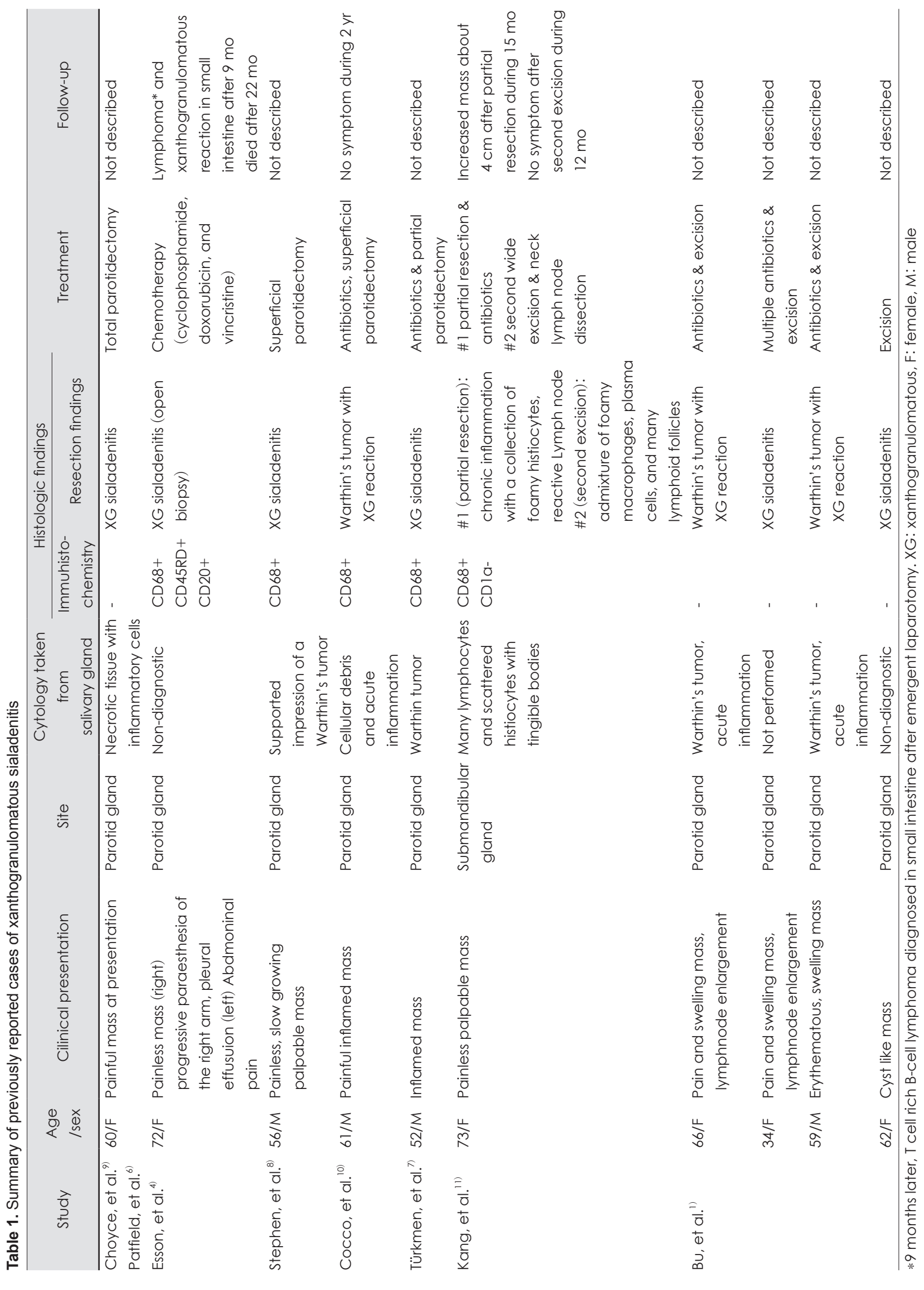


별이 특히 어려웠던 증례기에 이에 보고하는 바이다.

\section{Acknowledgments}

This study was supported by a National Research Foundation of Korea (NRF) grant funded by the Korean government (NRF2017R1A2B4007657 to SH Lee).

\section{Author Contribution}

Conceptualization: Sang Hyuk Lee. Formal analysis: Sun Woo Kim, Sang Hyuk Lee. Methodology: Sang Hyun Kim, Sun Woo Kim. Project administration: Sang Hyun Kim. Supervision: Sun Woo Kim, Sang Hyuk Lee. Validation: Sang Hyun Kim. Visualization: Sang Hyun Kim. Writing — original draft: Sang Hyun Kim. Writing_-review \& editing: Sang Hyun Kim, Sang Hyuk Lee.

\section{ORCIDs}

Sang Hyuk Lee https://orcid.org/0000-0003-4412-3486

Sang Hyun Kim

\section{REFERENCES}

1) Bu L, Zhu H, Racila E, Khaja S, Hamlar D, Li F. Xanthogranulomatous sialadenitis, an uncommon reactive change is often associated with Warthin's tumor. Head Neck Pathol 2020;14(2):525-32.

2) Eneroth CM. Facial nerve paralysis. A criterion of malignancy in parotid tumors. Arch Otolaryngol 1972;95(4):300-4.

3) Witt RL. Major salivary gland cancer. Surg Oncol Clin N Am 2004;13(1):113-27.

4) Esson MD, Bird E, Irvine GH. Lymphoma presenting as parotid xanthogranulomatous sialadenitis. Br J Oral Maxillofac Surg 1998;36(6):465-7.

5) Kim J, Kim SY, Jang Y, Yu J, Shim J, Kim H, et al.

Xanthogranulomatous pancreatitis mimicking pancreatic cancer. Korean J Pancreas Biliary Tract 2016;21(3):138-43.

6) Padfield CJ, Choyce MQ, Eveson JW. Xanthogranulomatous sialadenitis. Histopathology 1993;23(5):488-91.

7) Türkmen I, Başsüllü N, Aslan I, Çomunoğlu C, Doğusoy GB. Xanthogranulomatous sialadenitis clinically mimicking a malignancy: Case report and review of the literature. Oral Maxillofac Surg 2012;16(4):389-92.

8) Stephen MR, Matalka I, Stewart CJ, Mackenzie K. Xanthogranulomatous sialadenitis following diagnosis of Warthin's tumour: A possible complication of fine needle aspiration (FNA). Cytopathology 1999;10(4):276-9.

9) Choyce MQ, Padfield CJ, Mercer NS. Xanthogranulomatous sialadenitis, a benign mimic of malignancy. Br J Plast Surg 1993; 46(7):624-5.

10) Cocco AE, MacLennan GT, Lavertu P, Wasman JK. Xanthogranulomatous sialadenitis: A case report and literature review. Ear Nose Throat J 2005;84(6):369-70, 374.

11) Kang M, Kim NR, Chung DH, Seok JY, Kim DY. Primary necrobiotic xanthogranulomatous sialadenitis with submandibular gland localization without skin involvement. J Pathol Transl Med 2019;53(4):261-5.

12) Saade RE, Bell DM, Hanna EY. Benign neoplasms of the salivary glands. In: Flint P, Haughey B, Lund V, Niparko J, Robbins K, Thomas JR, et al., editor. Cummings Otolaryngology: Head and Neck Surgery. 6th ed. Philadelphia, PA: Elsevier;2015. p.1238-57.

13) Sabir Husin Athar PP, Yahya Z, Mat Baki M, Abdullah A. Facial nerve paralysis: A rare complication of parotid abscess. Malays J Med Sci 2009;16(2):38-9.

14) Kim HS, Joo M, Chang SH, Song HY, Song TJ, Seo JW, et al. Xanthogranulomatous pancreatitis presents as a solid tumor mass: A case report. J Korean Med Sci 2011;26(4):583-6. 